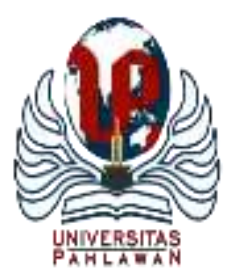

\title{
JURNALBASICEDU
}

Volume 6 Nomor 1 Tahun 2022 Halaman 1064 - 1074

Research \& Learning in Elementary Education

https://jbasic.org/index.php/basicedu

\section{Media Digital dalam Memberdayakan Kemampuan Berpikir Kritis Abad 21 pada Pembelajaran IPA di Sekolah Dasar}

\author{
Dewi Rahmawati Noer Jannah ${ }^{1 凶}$, Idam Ragil Widianto Atmojo ${ }^{2}$ \\ Universitas Sebelas Maret, Indonesia ${ }^{1,2}$ \\ E-mail: janahara66@ gmail.com ${ }^{1}$, idamragil@ fkip.uns.ac.id ${ }^{2}$
}

\begin{abstract}
Abstrak
Keterampilan berpikir kritis peserta didik pada pembelajaran Ilmu Pengetahuan Alam di sekolah dasar belum maksimal dikarenakan guru belum menggunakan media pembelajaran yang sesuai dengan karakteristik peserta didik maupun materi ajar. Tujuan penelitian ini untuk mendeskripsikan inovasi media digital dalam memberdayakan kemampuan berpikir kritis abad 21 pada pembelajaran Ilmu Pengetahuan Alam di sekolah dasar. Penelitian ini menggunakan desain penelitian literature review dengan pendekatan kualitatif. Data dalam penelitian ini adalah data sekunder. Teknik pengumpulan data menggunakan studi kepustakaan terkait buku, jurnal nasional, dan jurnal internasional sesuai fokus penelitian. Teknik analisis data berupa teknik analisis isi. Keabsahan data diuji dengan meningkatkan ketekunan penelitian. Hasil penelitian menunjukkan bahwa bentukbentuk inovasi media digital dalam memberdayakan kemampuan berpikir kritis abad 21 pada pembelajaran Ilmu Pengetahuan Alam di sekolah dasar, antara lain: game edukasi digital, video, youtube, power point, macromedial adobe flash, komik digital, e-book, flipbook, augmented reality, virtual reality, website pendidikan, televisi pendidikan, dan aplikasi pendidikan, seperti ruang guru, quipper school, dan kelas pintar.

Kata Kunci: media digital, berpikir kritis, pembelajaran IPA
\end{abstract}

\begin{abstract}
The critical thinking skills of students in learning Natural Sciences in elementary schools have not been maximized because teachers have not used learning media that are in accordance with the characteristics of students and teaching materials. The purpose of this study is to describe digital media innovations in empowering 21 st century critical thinking skills in natural science learning in elementary schools. This study uses a literature review research design with a qualitative approach. The data in this study are secondary data. The data collection technique uses literature studies related to books, national journals, and international journals according to the research focus. The data analysis technique is in the form of content analysis technique. The validity of the data was tested by increasing the persistence of the research. The results of the study show that forms of digital media innovation in empowering 21 st century critical thinking skills in natural science learning in elementary schools, including: digital educational games, videos, youtube, power point, macromedia/adobe flash, digital comics, e-commerce. books, flipbooks, augmented reality, virtual reality, educational websites, educational television, and educational applications, such as teacher rooms, quipper schools, and smart classrooms.
\end{abstract}

Keywords: digital media, critical thinking, science learning

Copyright (c) 2022 Dewi Rahmawati Noer Jannah, Idam Ragil Widianto Atmojo

$\triangle$ Corresponding author :

Email: janahara66@gmail.com

DOI : https://doi.org/10.31004/basicedu.v6i1.2124

ISSN 2580-3735 (Media Cetak)

ISSN 2580-1147 (Media Online) 
1065 Media Digital dalam Memberdayakan Kemampuan Berpikir Kritis Abad 21 pada Pembelajaran IPA di Sekolah Dasar - Dewi Rahmawati Noer Jannah, Idam Ragil Widianto Atmojo

DOI: https://doi.org/10.31004/basicedu.v6i1.2124

\section{PENDAHULUAN}

Ilmu Pengetahuan Alam (IPA) atau dikenal juga dengan Sains adalah suatu ilmu dengan topik pembahasannya mengenai gejala alam yang disusun secara sistematis berdasarkan hasil percobaan maupun pengamatan yang dilakukan oleh manusia (Samatoa, 2016: 1). Memiliki pemahaman terhadap ilmu pengetahuan alam dapat memberikan manfaat bagi kehidupan manusia mengingat manusia hidup selalu berdampingan dengan alam. Oleh karenanya, pendidikan IPA sudah diberikan sejak dini, yaitu pada jenjang sekolah dasar. Pengajaran IPA di sekolah dasar pada kurikulum 2013 memiliki bentuk penyajian materi yang berbeda antara kelas tinggi dan kelas rendah. Pembelajaran di kelas tinggi terdapat kompetensi dasar IPA sedangkan di kelas rendah tidak terdapat kompetensi dasar IPA. Meskipun begitu, keberadaan materi IPA tetap ada dan terintegrasi dengan kompetensi dasar lain, seperti Bahasa Indonesia. Tujuan adanya pengajaran IPA di sekolah agar peserta didik memiliki penguasaan terhadap pengetahuan, sikap ilmiah, dan keterampilan proses (Kumala, 2016: 10).

Pengajaran IPA di sekolah dasar perlu mengikuti perkembangan zaman karena pendidikan yang baik adalah pendidikan yang selalu berkembang mengikuti perubahan zaman. Pendidikan di abad 21 atau dikenal dengan era revolusi industry 4.0 berdampingan dengan pemanfaatan teknologi digital dan kecakapan pembelajaran abad 21. Kecakapan abad 21 atau 4C meliputi keterampilan berpikir kreatif (creative thinking), berpikir kritis dan pemecahan masalah (criticial thinking and problem solving), komunikasi (communication), dan kolaborasi (collaboration) (Partono et al., 2021). Tercapainya kecakapan abad 21 didukung dengan kemampuan pendidik dalam mengembangkan rencana pembelajaran yang memuat kegiatan-kegiatan 4C (Septikasari \& Frasandy, 2018).

Keterampilan 4C dapat digabungkan dengan pembelajaran IPA, sehingga diharapkan peserta didik dapat memecahkan beragam masalah yang ditemui di lingkungannya sehari-hari (Monica, Rizky, \& Estuhono, 2021). Oleh karenanya, untuk memunculkan keterampilan 4C dalam diri peserta didik pada pembelajaran IPA, maka guru perlu menjadi pendidik yang peka dan responsif terhadap kebutuhan peserta didik. Guru berperan dalam menghidupkan suasana belajar yang bergairah, menginspirasi, dan kreatif (Pramono et al., 2021). Guru juga dituntut untuk memiliki kompetensi yang baik dalam proses pembelajaran peserta didik (Yulyani et al., 2020).

Proses pembelajaran IPA perlu menggunakan bantuan benda-benda konkrit agar peserta didik memiliki pemahaman konsep yang baik tentang keadaan alam (Chan, 2017). Pemanfaatan benda-benda konkret tidak selalu mudah didapatkan, sehingga dibutuhkan kreativitas guru dalam mengelola media pembelajaran yang tepat dan efisien dalam mencapai tujuan pembelajaran IPA. Media pembelajaran adalah alat untuk menginformasikan pesan sehingga dapat merangsang pikiran, perasaan, perhatian, minat serta kemauan peserta didik dalam mencapai tujuan pembelajaran yang efektif (Sukiman, 2012: 29; Ramli, 2012: 2).

Pemanfaatan media pembelajaran dapat mendukung kelancaran proses pembelajaran IPA di sekolah dasar terutama dalam mengembangkan kemampuan 4C, yaitu salah satunya berpikir kritis. Keterampilan berpikir kritis sangat penting untuk memecahkkan permasalahan dalam kehidupan sehari-hari. Namun kenyataanya, penggunaan media pembelajaran di sekolah dasar belum dilaksanakan dengan maksimal. Permasalahan tersebut dapat ditemukan dalam penelitian terdahulu yang dilakukan oleh Ichsan et al. (2018) menunjukkan bahwa pembelajaran IPA di lingkungan sekolah dasar di Bekasi, Jawa Barat cenderung masih menggunakan media konvensional, seperti papan tulis dan buku cetak serta masih minimnya penggunaan media pembelajaran digital. Para guru merasa kesulitan dalam mengembangkan media pembelajaran IPA serta tidak memiliki banyak waktu untuk mengembangkan media pembelajaran. Penelitian tersebut juga mengungkapkan bahwa materi IPA di jenjang sekolah dasar mengandung banyak konsep pengetahuan alam sehingga banyak hafalan materi. Oleh sebab itu, perlu pertimbangan dalam pemberian media pembelajaran 
yang sesuai kebutuhan materi ajar, seperti materi pencemaran lingkungan, adaptasi makhluk hidup, gaya, listrik, dan perubahan wujud benda.

Sejalan dengan pernyataan sebelumnya, penelitian yang dilakukan Dwiqi, Sudatha, \& Sukmana, (2020) juga menunjukkan bahwa sumber belajar yang digunakan oleh guru masih menggunakan media konvensional, seperti bahan ajar cetak. Hal tersebut dikarenakan kurangnya kemampuan guru dalam mengembangkan media pembelajaran berbasis digital seperti media presentasi, video, animasi, ataupun multimedia interaktif lainnya. Kurangnya inovasi dalam media pembelajaran dapat menyebabkan hasil belajar peserta didik belum maksimal dan motivasi belajar peserta didik rendah sehingga peserta didik mudah bosan dalam mengikuti pembelajaran terutama pada materi yang bersifat abstrak. Kurang maksimalnya pemanfaatan media ajar pada setiap mata pelajaran juga ditemukan pada penelitian terdahulu yang dilakukan oleh Monica, Ricky, \& Estuhono (2021), sehingga keterampilan $4 \mathrm{C}$ pada peserta didik belum tercapai dengan baik.

Hasil penelitian pendahuluan kepada beberapa guru sekolah dasar di Boyolali, juga menunjukkan bahwa pembelajaran IPA lebih cenderung menghafalkan daripada melakukan eksplorasi dalam pembelajaran IPA, sehingga peserta didik mudah bosan, kurang aktif dalam memberikan pendapat, dan dalam mengerjakan soal IPA kurang tepat. Hal tersebut disebabkan salah satunya karena pemanfaatan dan inovasi media pembelajaran di sekolah belum maksimal. Oleh karenanya, beberapa media pembelajaran yang tersedia di sekolah mudah rusak, seperti media KIT. Sejalan dengan hal tersebut, beberapa upaya yang guru lakukan, yaitu guru terkadang menggunakan media digital, seperti video dan power point. Pemanfaatan media pembelajaran berupa video dan power point perlu menyesuaikan keadaan karena tidak semua kelas memiliki LCD dan tidak semua guru paham terhadap teknologi digital baik dalam pengoperasian maupun dalam tahap perencanaan, seperti perlu mencari video yang menarik dan sesuai dengan materi ajar serta perlu kreativitas dalam penyusunan power point agar slide menarik, tidak monoton, dan mudah dipahami peserta didik. Meskipun begitu, pemanfaatan video maupun power point dapat menjadikan waktu mengajar lebih efektif dan fokus peserta didik menjadi lebih baik karena terdapat visualisasi daripada hanya membaca teks.

Permasalahan dalam pembelajaran IPA terkait pemanfaatan media pembelajaran harus segera diatasi agar tujuan pembelajaran IPA dapat tercapai secara efektif dalam mengembangkan kemampuan peserta didik baik dalam aspek kognitif, afektif, maupun psikomotorik. Oleh sebab itu, dalam proses pembelajaran IPA terutama untuk mendukung pemikiran kritis tingkat tinggi pada peserta didik Gen $\mathrm{Z}$ diperlukan strategi ideal (Ramadhani, Zulela, \& Fahrurrozi, 2021). Pada pembelajaran abad 21 ini, media digital menjadi salah satu pilihan yang dapat digunakan guru untuk memberikan pemahaman yang bermakna sekaligus menyenangkan bagi peserta didik. Media pembelajaran digital adalah media pembelajaran yang menghasilkan sebuah citra digital yang dapat diolah, diakses, dan didistribusikan menggunakan perangkat digital (Batubara, 2021: 327). Media pembelajaran digital juga dikenal dengan multimedia, yaitu salah satu jenis media pembelajaran yang dapat merangsang minat belajar peserta didik terhadap suatu materi dengan memanfaatkan media digital dalam bentuk gambar, audio, video, maupun animasi (Purwati, 2021; Nurdyansyah, 2019: 94-100). Pembelajaran berbasis media digital dapat memfasilitasi kegiatan pembelajaran lebih luas, bervariasi serta pembelajar dapat belajar kapan dan di mana saja tanpa terbatas jarak, ruang, dan waktu (Munir, 2017: 4). Pemanfaatan teknologi digital sekarang ini yang mempengaruhi peserta didik antara lain augmented reality, virtual reality, mobile learning, game base learning, cloud learning, redesigned learning spaces (smartboards), artificial intelligence (Hasan et al., 2021: 55). Media pembelajaran digital lainnya, yaitu Powtoon, Kahoot!, Quizziz, Power point, VideoScribe, dan lain - lain (Istyasiwi, Auliaty, \& Sholeh, 2021).

Berpijak dari permasalahan yang telah dipaparkan maka penting untuk melakukan inovasi terhadap media pembelajaran dalam menunjang kecakapan di abad 21 ini dengan tetap menyesuaikan karakteristik peserta didik maupun materi ajar, salah satunya dengan pemanfaatan media digital. Oleh karenanya, tujuan dalam penelitian ini adalah mendeskripsikan inovasi media digital dalam memberdayakan kemampuan berpikir kritis abad 21 pada pembelajaran IPA di sekolah dasar. Penelitian ini bermanfaat sebagai dasar 
analisis kebutuhan pemanfaatan media digital untuk mendukung proses perbaikan pada pembelajaran IPA di SD dalam meningkatkan penguasaan keterampilan 4C, salah satunya berpikir kritis.

\section{METODE PENELITIAN}

Penelitian ini menggunakan desain penelitian studi kepustakaan (literature review) dengan pendekatan kualitatif. Data dala penelitian ini berupa data sekunder yang diperoleh melalui teknik pengumpulan data menggunakan studi kepustakaan, yaitu berupa analisis terhadap sumber data dari jurnal nasional dan jurnal internasional terbitan 5 tahun terakhir serta melalui kajian pada buku. Instrument penelitian studi kepustakaan ini adalah peneliti sendiri, yaitu peneliti menggunakan lembar checklist untuk menyeleksi berbagai artikel yang sesuai dengan topik penelitian. Prosedur penelitian ini meliputi 1) menentukan tema penelitian, yaitu inovasi media pembelajaran digital dalam memberdayakan kemapuan berpikir kritis abad 21 pada pembelajaran IPA di sekolah dasar; 2) mencari dan mengumpulkan berbagai artikel di website sinta, scopus, web of science, google scholar, dan website lainnya; c) mengklasifikasikan berbagai jenis artikel yang relevan dengan tema penelitian, d) mensintesis artikel yang relevan dengan menandai poin-poin penting pada setiap artikel; dan e) menulis artikel dari hasil sintesis. Teknik analisis dalam penelitian ini berupa teknik analisis isi (content analysis), yaitu mempelajari gambaran isi, karakteristik pesan, dan perkembangan (term) dari suatu isi (Eriyanto, 2013: 11). Pengujian keabsahan data dalam penelitian studi kepustakaan ini adalah dengan meningkatkan ketekunan penelitian, meliputi: 1) peneliti melakukan pengecekan antar pustaka, yaitu dengan membaca berbagai pustaka baik dari buku, hasil penelitian terdahulu, maupun dokumentasi-dokumentasi yang terkait dengan temuan. Hal tersebut berguna untuk membuat wawasan peneliti semakin luas dan tajam sehingga data yang ditemukan tidak hanya data yang tersurat saja tetapi juga tersirat; 2) membaca ulang pustaka yang dianalisis dengan berpedoman pada fokus permasalahan. Hal tersebut berguna untuk memeriksa keakuratan data yang didapat baik secara tersurat maupun tersirat, sehingga data yang ditemukan dapat dipercaya kebenarannya, dan 3) memperhatikan komentar pembimbing baik dari segi perencanaan, pengumpulan, maupun penulisan data terkait hasil temuan.

\section{HASIL DAN PEMBAHASAN}

Berdasarkan hasil kajian literature dari beberapa penelitian terdahulu menunjukkan bahwa pemanfaatan media digital interaktif dapat mendukung penguasaan keterampilan $4 \mathrm{C}$, salah satunya pada keterampilan berpikir kritis. Hal tersebut dapat ditemukan pada penelitian milik Priyani \& Nawawi (2020) yang menyatakan bahwa penggunaan teknologi, seperti mikroskop digital menjadi sebuah solusi di daerah perbatasan khususnya di kelas 4 SDN 29 Idai untuk memiliki pemahaman mendalam terhadap pembelajaran IPA pada materi bagian tumbuhan dan fungsinya. Mikroskop digital tersebut dapat diintegrasikan dengan perangkat handphone android yang dimiliki oleh guru. Penggunaan media ajar berbantuan mikroskop digital menjadikan peserta didik mengalami peningkatan hasil belajar terutama dalam kemampuan berpikir kritis yang terwujud dalam pencapaian keterampilan proses pada peserta didik, meliputi 1) kemampuan mengaplikasikan 58,33\%,2) kemampuan menyimpulkan 56,25\%; 3) kemampuan mengajukan hipotesis $54,17 \%$; 4) kemampuan memprediksi peserta didik $56,25 \%$; 5) kemampuan mengklasifikasikan peserta didik $54,17 \%$; dan 6) kemampuan mengamati atau mengobservasi 64,58\%.

Penelitian terdahulu yang dilakukan oleh Istyasiwi et al., (2021), juga menunjukkan adanya peningkatan berpikir kritis melalui media digital kartu DORAMA serta dapat meningkatkan minat dan motivasi belajar peserta didik. Media digital kartu DORAMA merupakan media edukasi permainan yang berbentuk aplikasi berbasis andorid dan dikembangkan untuk peserta didik kelas 5 SD dalam mempelajari materi rantai makanan dan jaring - jaring makanan. Media ini sebagai inovasi baru dalam media pembelajaran untuk guru dan peserta didik melakukan kegiatan belajar sambil bermain. Android juga bisa digunakan untuk 
mengakses bahan ajar digital, seperti yang diungkapkan dalam penelitian Maskur \& Safitri (2021) menunjukkan bahwa bahan ajar digital berbasis android untuk peserta didik berkebutuhan khusus pada mata pelajaran IPA dinyatakan efektif digunakan dalam pembelajaran. Media pembelajaran selain bahan ajar digital berbasis android, yaitu video, youtube, dan power point juga mendukung peserta didik dalam memahami suatu materi.

Sejalan dengan temuan pada penelitian sebelumnya, penelitian yang dilakukan Risky (2019) juga menunjukkan penggunaan media video pada mata pelajaran IPA di kelas 5 SD Muhammadiyah 1 Tulungagung dapat menumbuhkan perhatian dan menambah kemudahan peserta didik dalam memahami materi pelajaran IPA serta sesuai dengan karakteristik belajar peserta didik generasi digital. Penggunaan media video juga ditemukan pada penelitian terdahulu milik Sunami \& Aslam (2021) yang menyatakan bahwa penggunaan media video animasi pada materi siklus air dapat meningkatkan minat dan hasil belajar peserta didik serta memudahkan membagikan materi pembelajaran dan bisa digunakan kapan saja saat dibutuhkan. Kuncoro \& Hidayati (2021) dalam penelitiannya juga menemukan bahwa video pembelajaran dapat meningkatkan hasil belajar kognitif peserta didik pada materi daur hidup hewan. Salah satu bentuk tampilan video pembelajaran yang menarik, yaitu animasi. Video animasi adalah multimedia yang menggabungkan gambar, teks, audio, animasi, dan video. Animasi digital mampu menarik perhatian peserta didik dalam mengembangkan pemahaman tentang mata pelajaran tertentu serta menstimulasi keaktifan dan keterampilan baru pada peserta didik (Rizkasari et al., 2021). Penggunaan video juga bisa didapatkan pada youtube. Penelitian yang dilakukan oleh Wulandari, Matsuri, Fakhriyah (2021) menunjukkan bahwa pembelajaran menggunakan media berbasis youtube memiliki hasil belajar IPA yang lebih baik dibandingkan kelas yang tidak menggunakan media pembelajaran berbasis youtube pada peserta didik kelas 5 SDN Karangsari 01 dan SDN Karangsari 03. Peserta didik terlihat lebih bersemangat dan lebih aktif dalam mengikuti proses pembelajaran.

Media interaktif yang dapat mengembangkan pembelajaran IPA, selain video dari youtube, yaitu media power point. Penelitian yang dilakukan Hayyuningtyas \& Batubara (2021) menunjukkan pemanfaatan media interaktif berbasis powerpoint dan ispring di Android layak untuk digunakan. Pengembangan tersebut bertujuan agar kegiatan mengajar dapat lebih efektif dan maksimal meskipun pembelajaran di lakukan tanpa tatap muka. Pengembangan media pembelajaran tersebut melewati beberapa proses, yaitu pembuatan slide power point yang diisi dengan konten materi yaitu pernapasan pada hewan, lalu memberikan tombol tombol sebagai opsi untuk mengklik slide yang diinginkan.

Media pembelajaran digital berbasis adobe flash yang diterapkan di sekolah dasar juga dapat memperjelas dalam penyampaian informasi pembelajaran. Macromedia flash atau adobe flash merupakan sebuah program aplikasi yang mampu menciptakan multimedia interaktif yang menarik seperti game, presentasi, web, animasi pembelajaran, bahkan pembuatan film, yang memiliki fasilitas yang sangat bagus dalam menghasilkan suatu animasi. Penelitian yag dilakukan Purwati (2021) menunjukkan bahwa macromedia flash memiliki dampak positif yang meliputi: 1) meningkatnya minat peserta didik dalam pembelajaran dan membuat peserta didik mandiri; 2) dapat meningkatkan motivasi belajar; dan 3) meningkatkan hasil belajar peserta didik dan kemampuan berpikir kritis pada peserta didik seperti dalam pembelajaran IPA, yaitu pada materi sifat-sifat bunyi dan keterkaitannya dengan indera pendengaran.

Media pembelajaran komik digital juga memiliki dampak positif dalam pembelajaran IPA di sekolah dasar yang dapat ditemukan dalam penelitian milik Siregar \& Siregar (2021) yang meliputi: 1) minat belajar peserta didik untuk mata pelajara IPA khususnya pada materi gerhana sangat antusias sehingga efektifitas peserta didik terhadap pembelajaran tersebut semakin tinggi; 2) media komik digital pada mata pelajaran IPA dapat membantu guru dalam menyampaikan materi yang lebih mudah dimengerti oleh anak sehingga proses pembelajaran menjadi menarik bagi peserta didik; 3) peserta didik mejadi lebih semangat dalam belajar terutama pada mata pelajaran IPA; dan 4) media komik digital gerhana pada mata pelajaran IPA sangat layak 
dijadikan media pembelajaran yang menarik dan edukatif sehingga meningkatkan hasil capaian evaluasi peserta didik pada keterampilan berpikir kritis. Pemanfaatan media pembelajaran digital juga ditemukan pada penelitian Pinatih \& Putra (2021) yang dilatarbelakangi oleh terbatasnya variasi media pembelajaran yang dimiliki guru dalam proses pembelajaran IPA sehingga peserta didik kekurangan media untuk membantunya belajar secara mandiri. Hasil penelitian tersebut menyimpulkan bahwa komik digital layak digunakan di sekolah dasar terutama pada pembelajaran IPA karena desainnya menarik, cerita dalam komik digital mengandung pengalaman belajar 5M sebagai ciri pendekatan saintifik dan media komik digital bersifat praktis dan mudah diakses. Sejalan dengan penelitian sebelumnya, penelitian yang dilakukan Sari et al., (2021) juga menunjukkan bahwa pengembangan komik digital dalam pemeblajaran IPA di SD efektif dan memudahkan peserta didik belajar IPA baik secara online maupun offline serta dengan desain yang menarik peserta didik tidak mudah bosan dalam memahami materi yang menyatu dalam cerita pada komik digital tersebut. Pemanfaatan media komik digital dalam penelitian tersebut diawali dengan tahap analisis kurikulum, materi, tujuan pembelajaran, serta desain gambar komik. Media komik digital sebagai inovasi dalam menghadirkan pembelajaran abad 21 di kelas harus memperhatikan pemilihan topik cerita agar pesan dan tujuan pembelajaran dapat tersampaikan (Wicaksono, Japar, \& Utomo 2021). Penelitian terdahulu yang dilakukan oleh Rina et al., (2020) juga mengemukakan manfaat media digital untuk meningkatkan keterampilan literasi membaca dalam pembelajaran abad 21. Membaca merupakan keterampilan berbahasa yang sangat penting untuk mendapatkan informasi baru sehingga peserta didik mampu berpikir kritis melalui pengetahuan yang diterima dari kegiatan membaca.

Peningkatan keterampilan berpikir kritis melalui pemanfaatan media digital juga ditemukan dalam penelitian Aisyah, Supriyani, \& Hawaliyah (2021) yang menunjukkan bahwa penggunaan media komputer interaktif mampu meningkatkan minat belajar, motivasi, dan pemahaman peserta didik terhadap materi yang diberikan, sehingga dapat meningkatkan hasil belajar IPA khususnya tentang gaya. Permasalahan dalam pembelajaran IPA terkait materi gaya juga diungkapkan pada penelitian milik Aprilia (2021) yang menunjukkan adanya persepsi peserta didik mengenai buku cetak pembelajaran yang digunakan, yaitu kurang menarik, kurang berwarna, terlalu banyak teksnya, serta kurang praktis karena berat dalam membawanya. Selain itu, meskipun ada buku BSE yang dikemas dalam bentuk e-book, namun buku BSE e-book tersebut juga tidak jauh berbeda dengan buku cetak lainnya yang banyak beredar. Media pembelajaran Sains flipbook berbasis kontekstual merupakan pengembangan dari e-book sebagai salah satu alternatif yang media pembelajaran yang terbukti dapat meningkatkan kemampuan berpikir kritis pada pembelajaran IPA di kelas 5 SD Semester 2 pada materi gaya dan pesawat sederhana dibanding hanya menggunakan media buku paket IPA. Penggunaan media sains flipbook mempermudah guru dalam menyampaikan materi dalam mata pelajaran IPA dengan menggunakan media sains flipbook serta bagi peserta didik memudahkan untuk memahami materi yang diajarkan guru pada mata pelajaran IPA. Selain itu, dengan adanya media sains flipbook yang berisi berbagai konten interaktif, menyenangkan dan berbasis kontektual sesuai dengan kehidupan sehari-hari peserta didik, seperti video pembelajaran, teks disertai contoh penerapannya dalam bentuk gambar konkret, kuis, dan berbagai aktivitas kegiatan lainnya, sangat efektif untuk melatih kemandirian belajar peserta didik dan kemampuan berpikir kritis peserta didik sekolah dasar. Pengembangan media digital flipbook juga ditemukan pada penelitian Perdana, Wibowo, \& Budiarto (2021) yang memiliki peran penting dalam mendukung terciptanya lingkungan belajar, sehingga memudahkan peserta didik dalam belajar. Pentingnya pengaruh media digital flipbook mengenai materi IPA tidak hanya berlaku di sekolah dasar saja melainkan juga dimanfaatkan hingga pendidikan lebih tinggi, seperti SMA (Ristanto, Mahardika, \& Rusdi, 2021).

Pemanfaatan media digital lainnya, yaitu e-book berbasis mind mapping. Penelitian yang dilakukan Nurlaela, Sumantri, \& Sakardi (2021) menyatakan bahwa e-book berbasis mind mapping dapat memvisualisasikan konsep abstrak menjadi konsep konkret dan seolah-olah dapat dipahami, seperti objek 
ilmiah yang sangat kecil sehingga sulit dilihat secara langsung atau bahkan sangat besar sehingga tidak mungkin disajikan di dalam kelas. Dengan memanfaatkan media berbasis e-book based mind mapping memberikan solusi dari permasalahan tersebut. Pemanfaatan $e$-book memerlukan fasilitas penunjang seperti akses internet, komputer/laptop, handphone dan kemampuan guru atau peserta didik dalam mengakses $e$-book (Dewi \& Agung, 2021). Untuk melihat kemampuan peserta didik dalam memahami materi dalam e-book guru bisa memberikan tes kepada peserta didik. Pengerjaan tes pada peserta didik bisa dilakukan melalui lembar kerja digital. Hal tersebut didukung dengan penelitian yang dilakukan Ichsan et al., (2020) berupa pemanfaatan media digital berbasis model ILMIZI terbukti layak digunakan dan mampu mengembangkan kemampuan berpikir tingkat tinggi pada peserta didik meskipun dalam pembelajaran e-learning.

Pemanfaatan multimedia dalam pembelajaran sains dalam penelitian Chen (2020) berbentuk media Augmented Reality (AR) dan permainan digital. Media tersebut terbukti dapat memudahkan peserta didik memahami konsep IPA serta meningkatkan motivasi belajar. Media permainan digital dapat digunakan dalam pembelajaran online dan tatap muka (Fitriana et al., 2021). Pengembangan media dalam pembelajaran IPA ada yang berbentuk Virtual Reality (VR). Pengembangan media VR yang dilakukan di SDS Muhammadiyah 9 Jakarta memiliki desain visual yang menyerupai benda asli sehingga dapat membantu peserta didik memahami konsep abstrak yang sulit pada materi anatomi manusia serta memudahkan berimajinasi dan mevisualkan secara langsung (Zulherman et al., 2021).

Pemanfaatan media digital juga didukung oleh kemendikbud sebagai media pembelajaran yang efektif selama pembelajaran daring. Beberapa upaya yang dilakukan Kemendikbud, meliputi menyediakan tayangan pendidikan di televisi, memberikan pelayanan edukatif secara gratis seperti, Ruang Guru, Quipper School, Kelas Pintar, dan lain sebagainya. Selama pembelajaran berbasis online ini, peserta didik tetap dipantau oleh guru melalui Whatsapp Grup sehingga anak betul-betul belajar dengan cara berkordinasi melalui para orang tua peserta didik dengan video call atau mendokumentasikan kegiatan belajar anak di rumah (Garini, Respati, dan Mulyadiprana, 2020). Pemanfaatan website internet juga mampu menambah wawasan peserta didik untuk berpikir kritis (Astuti et al., 2020).

Pembelajaran abad 21 ini berdampingan dengan pemanfaatan media digital atau teknologi dasar. Pemanfaatan media digital dalam pembelajaran abad 21 bertujuan untuk menunjang keefektifan dalam kecakapan 4C, yang meliputi kemampuan berpikir kritis, kemampuan berpikir kreatif, kemampuan komunikasi, kemampuan elaborasi, kemampuan teknologi dan informasi (Lubis \& Lubis, 2021). Ariyana et al., (2018: 15) juga mengungkapkan bahwa 1) Keterampilan berpikir kreatif dan inovatif, yaitu peserta didik dapat menghasilkan, mengembangkan, dan mengimplementasikan ide-ide mereka secara kreatif baik secara mandiri maupun berkelompok; 2) Keterampilan berpikir kritis dan memecahkan masalah, yaitu peserta didik dapat mengidentifikasi, menganalisis, menginterpretasikan, dan mengevaluasi bukti-bukti, argumentasi, klaim dan data-data yang tersaji secara luas melalui pengakajian secara mendalam, serta merefleksikannya dalam kehidupan sehari- hari; 3) Keterampilan berkomunikasi, yaitu peserta didik dapat mengkomunikasikan ide-ide dan gagasan secara efektif menggunakan media lisan, tertulis, maupun teknologi dan 4) Keteranpilan dalam berkolaborasi, yaitu peserta didik dapat bekerja sama dalam sebuah kelompok dalam memecahkan permsalahan yang ditemukan.

Berdasarkan hasil kajian literature review dari penelitian terdahulu, maka diperlukan inovasi pemanfaatan media digital untuk menanamkan dan memberdayakan kemampuan beripikir kritis peserta didik pada pembelajaran IPA di SD. Meskipun begitu, pada masa pandemi Covid-19 ini keterampilan berpikir kritis yang terdiri dari merumuskan masalah, menganalisis dan memecahkan masalah, serta mengevaluasi dalam pembelajaran IPA belum terintegrasi dengan baik di sekolah dasar. Oleh karenanya, guru perlu menata pembelajaran kreatif dalam menerapkan strategi pembelajaran yang tepat agar keterampilan berpikir kritis dalam pembelajaran IPA dapat tercapai dengan baik oleh peserta didik (Prafitasari et al., 2021). Peningkatan kemampuan berpikir kritis dapat dilakukan melalui pemilihan media yang sesuai. Media yang dimaksud 
adalah multimedia pembelajaran interaktif, karena disesuaikan dengan karakteristik peserta didik yang merupakan digital natives (Fitriani, Suwarjo, \& Wangid, 2021).

\section{KESIMPULAN}

Kemampuan berpikir kritis merupakan salah satu keterampilan abad 21 yang diperlukan peserta didik dalam memecahkan masalah di kehidupan nyata. Pengembangan kemampuan berpikir kritis dapat dilakukan melalui pemanfaatan media pembelajaran, yaitu media digital. Media digital adalah media pembelajaran yang menerapkan pemanfaatan teknologi, informasi, dan komunikasi. Media digital dalam pembelajaran IPA memiliki manfaat, yaitu mengefektifkan tercapainya tujuan pembelajaran IPA, menarik perhatian belajar peserta didik, memudahkan peserta didik memahami konsep materi IPA yang sulit atau abstrak, serta mengembangkan kecakapan 4C, salah satunya kemampuan berpikir kritis. Bentuk-bentuk inovasi media digital dalam memberdayakan kemampuan berpikir kritis abad 21 pada pembelajaran IPA di sekolah dasar, antara lain: game edukasi digital, video, youtube, power point, macromedial adobe flash, komik digital, $e$ book, flipbook, augmented reality (AR), virtual reality (VR), website pendidikan, TV pendidikan, dan aplikasi pendidikan (ruang guru, quipper school, kelas pintar).

\section{DAFTAR PUSTAKA}

Aisyah, N., Supriyani, Y., \& Hawaliyah, N. (2021). Upaya Meningkatkan Hasil Belajar Ipa Melalui Penggunaan Media Komputer Interaktif Dan Metode Demonstrasi. Jurnal Ideas: Pendidikan, Sosial, Dan Budaya, 7(1), 11-20. Https://Doi.Org/10.32884/Ideas.V

Aprilia, T. (2021). Efektivitas Penggunaan Media Sains Flipbook Berbasis Kontekstual Untuk Meningkatkan Kemampuan Berfikir Kritis Siswa. Jurnal Penelitian Ilmu Pendidikan, 14(1), 10-21. Https://Doi.Org/Https://Doi.Org/10.21831/Jpipfip.V14i1.32059

Ariyana, Y., Pudjiastuti, A., Bestary, R., \& Zamromi. (2018). Buku Pegangan Pembelajaran Berorientasi Pada Keterampilan Berpikir Tingkat Tinggi. In Direktorat Jendral Guru Dan Tenaga Kependidikan. Kementrian Pendidikan Dan Kebudayaan Republik Indonesia.

Astuti, L., Wihardi, Y., \& Rochintaniawati, D. (2020). The Development Of Web-Based Learning Using Interactive Media For Science Learning On Levers In Human Body Topic. Journal Of Science Learning, 3(August 2019), 89-98. Https://Doi.Org/10.17509/Jsl.V3i2.19366

Batubara, H. H. (2021). Media Pembelajaran Digital. Bandung: Remaja Rosdakarya.

Chan, F. (2017). Implementasi Guru Menggunakan Metode Permainan Pada Pelajaran Ipa Di Sekolah Dasar. Jurnal Gentala Pendidikan Dasar, 2(1), 106-123. Https://Doi.Org/10.22437/Gentala.V2i1.6821

Chen, C. H. (2020). Impacts Of Augmented Reality And A Digital Game On Students' Science Learning With Reflection Prompts In Multimedia Learning. Educational Technology Research And Development. Https://Doi.Org/10.1007/S11423-020-09834-W

Dewi, N. K. R., \& Agung, A. A. G. (2021). The Feasibility Of Social Science Learning E-book Contains Balinese Local Wisdom For Elementary School. International Journal Of Elementary Education, 5(1), $39-47$.

Dwiqi, G. C. S., Sudatha, I. G. W., \& Sukmana, A. I. W. I. Y. (2020). Pengembangan Multimedia Pembelajaran Interaktif Mata Pelajaran Ipa Untuk Siswa Sd Kelas V. Jurnal Edutech Universitas Pendidikan Ganesha, 8(2), 33-48.

Eriyanto. (2013). Analisi Isi (Pengantar Metodologi Untuk Penelitian Ilmu Komunikasi Dan Ilmu-Ilmu Sosial Lainnya). Jakarta: Kencana Prenada Media Group. 
1072 Media Digital dalam Memberdayakan Kemampuan Berpikir Kritis Abad 21 pada Pembelajaran IPA di Sekolah Dasar - Dewi Rahmawati Noer Jannah, Idam Ragil Widianto Atmojo

DOI: https://doi.org/10.31004/basicedu.v6i1.2124

Fitriana, L., Hendriyanto, A., Sahara, S., \& Akbar, F. N. (2021). Digital Literacy: The Need For TechnologyBased Learning Media In The Revolutionary Era 4.0 For Elementary School Children. International Journal Of Progressive Sciences And Technologies (Ijpsat), 26(1), 194-200.

Fitriani, W., Suwarjo, \& Wangid, M. N. (2021). Berpikir Kritis Dan Komputasi : Analisis Kebutuhan Media Pembelajaran Di Sekolah Dasar. Jurnal Pendidikan Sains Indonesia, 9(2), 234-242. Https://Doi.Org/10.24815/Jpsi.V9i2.19040

Garini, A. W., Respati, R., \& Mulyadiprana, A. (2020). Penggunaan Media Berupa Digital Pada Masa Pandemi Di Sekolah Dasar. Pedadiktika: Jurnal Ilmiah Pendidikan Guru Sekolah Dasar, 7(4), 186-191.

Hasan, M., Munfangati, R., Mustika, Supartha, I. K. D. G., Tyaningsih, R. Y., Satria, R., Thalib, D., Lestari, A. S., Subagiyo, A., Ariningsih, K. A., Hasbi, I., \& Khaira., I. (2021). Pembelajaran Digital (1st Ed.). Widina Bhakti Persada.

Hayyuningtyas, K., \& Batubara, H. H. (2021). Pengembangan Media Pembelajaran Interaktif Berbasis Powerpoint Dan Ispring Di Android Untuk Meningkatkan Efektifitas Pembelajaran Ipa Di Kelas 3 Sd. Mubtadi: Jurnal Pendidikan Ibtidaiyah, 3(1), 61-69.

Ichsan, I. Z., Dewi, A. K., Hermawati, F. M., \& Iriani, E. (2018). Pembelajaran Ipa Dan Lingkungan: Analisis Kebutuhan Media Pembelajaran Pada Sd, Smp, Sma Di Tambun Selatan, Bekasi Ilmi. Jipva (Jurnal Pendidikan Ipa Veteran), 2(2), 131-140.

Ichsan, I. Z., Rahmayanti, H., Purwanto, A., Sigit, D. V., Singh, C. K. S., \& Babu, R. U. M. (2020). HotsAep-Covid-19: Students Knowledge And Digital Worksheet Of Ilmizi Environmental Learning Model. International Journal Of Advanced Science And Technology (Ijast), 29(6), 5231-5241.

Istyasiwi, M. E., Aulianty, Y., \& Sholeh, D. A. (2021). Pengembangan Media Digital Kartu Domino Rantai Makanan (Dorama) Pada Pembelajaran Ipa Di Sekolah Dasar. Prima Magistra: Jurnal Ilmiah Kependidikan, 2(2), 254-263. Https://Doi.Org/10.37478/Jpm.V2i2.1115

Kumala, F. N. (2016). Pembelajaran Ipa Sekolah Dasr. Malang: Ediide Infografika.

Kuncoro, I. A., \& Hidayati, Y. M. (2021). Learning Videos Increase Students' Cognitive Learning Outcomes On Animal Life Cycle Materials. Jurnal Ilmiah Sekolah Dasar (Jisd), 5(2), 299-306.

Lubis, N., \& Lubis, A. (2021). Pembelajaran Abad 21 Dengan Implementasi Experiential- Based Learning Bagi Guru Sd N 101789 Marindal I Kabupaten Deli Serdang. Amaliah: Jurnal Pengabdian Kepada Masyarakat, 5(1), 1-6.

Maskur, \& Safitri, E. R. (2021). Efektivitas Penggunaan Bahan Ajar Digital Berbasis Android Dalam Pembelajaran Ipa Pada Siswa Berkebutuhan Khusus. Joeai (Journal Of Education And Instruction), 4(1), 47-53. Https://Doi.Org/Https://Doi.Org/10.31539/Joeai.V4i1.2149

Monica, R., Ricky, Z., \& Estuhono. (2021). Pengembangan Modul Ipa Berbasis Model Research Based Learning Pada Keterampilan 4c Siswa Sekolah Dasar. Edukatif: Jurnal Ilmu Pendidikan, 3(6), 44704482. Https://Doi.Org/Https://Doi.Org/10.31004/Edukatif.V3i6.1470

Munir. (2017). Pembelajaran Digital. Bandung: Alfabeta.

Nurdyansyah. (2019). Media Pembelajaran Inovatif (1st Ed.). Sidoarjo: Umsida Press.

Nurlaela, E., Sumantri, M., \& Sarkadi. (2021). Development Of Mind Mapping Based E-book In Steam For Skills Of Grade Vi Elementary School Students. International Journal Of Multicultural And $\begin{array}{lll}\text { Multireligious } & \text { Understanding, } & \text { 390-399. }\end{array}$ Https://Doi.Org/Http://Dx.Doi.Org/10.18415/Ijmmu.V8i6.2787

Partono, Wardhani, H. N., Setyowati, N. I., Tsalitsa, A., \& Putri, S. N. (2021). Strategi Meningkatkan Kompetensi 4c (Critical Thinking, Creativity, Communication, \& Collaborative). Jurnal Penelitian Ilmu Pendidikan, 14(1), 41-52. Https://Doi.Org/10.21831/Jpipfip.V14i1.35810

Perdana, M. A., Wibowo, D. E., \& Budiarto, M. K. (2021). Digitalization Of Learning Media Through Digital 
1073 Media Digital dalam Memberdayakan Kemampuan Berpikir Kritis Abad 21 pada Pembelajaran IPA di Sekolah Dasar - Dewi Rahmawati Noer Jannah, Idam Ragil Widianto Atmojo

DOI: https://doi.org/10.31004/basicedu.v6i1.2124

Book Development Using The Flipbook Application. Jurnal Pendidikan Pengajaran (Jpp), 54(2), 263272. Https://Doi.Org/Http://Dx.Doi.Org/10.23887/Jpp.V54i2

Pinatih, S. A. C., \& Putra, D. K. N. S. (2021). Pengembangan Media Komik Digital Berbasis Pendekatan Saintifik Pada Muatan Ipa. Jurnal Penelitian Dan Pengembangan Pendidikan, 5(1), 115-121.

Prafitasari, F., Sukarno, \& Muzzazinah. (2021). Integration Of Critical Thinking Skills In Science Learning Using Blended Learning System. International Journal Of Elementary Education, 5(3), 434-445.

Pramono, A., Pujiyanto, Puspasari, B. D., \& Dhanti, N. S. (2021). Character Thematic Education Game “Ak@R" Of Society Themes For Children With Malang-Indonesian Visualize. International Journal Of Instruction, 14(2), 179-196. Https://Doi.Org/Https://Doi.Org/10.29333/Iji.2021.14211a

Priyani, N. E., \& Nawawi. (2020). Pembelajaran Ipa Berbasis Ethno-Stem Berbanti Mikroskop Digital Untuk Meningkatkan Keterampilan Proses Sains Di Sekolah Perbatasan. Wasis: Jurnal Ilmiah Pendidikan, 1(2), 99-104.

Purwati, L. M. (2021). Media Pembelajaran Digital Interaktif Berbasis Adobe Flash Pada Masa Pandemi Di Sekolah Dasar. Autentik: Jurnal Pengembangan Pendidikan Dasar, 5(2), 152-158.

Ramadhani, S. P., Zulela, \& Fahrurrozi. (2021). Analisis Kebutuhan Desain Pengembangan Model Ipa Berbasis Project Based Learning Untuk Meningkatkan Berpikir Kritis Siswa Di Sekolah Dasar. Jurnal Basicedu, 5(4), 1819-1824.

Ramli, M. (2012). Media Dan Teknologi Pembelajaran. Banjarmasin: Antasari.

Rina, N., Suminar, J. R., Damayani, N. A., \& Hafiar, H. (2020). Character Education Based On Digital Comic Media. Ijim, 14(3), 107-127. Https://Doi.Org/Https://Doi.Org/10.3991/Ijim.V14i03.12111 Nofha

Risky, S. M. (2019). Analisis Penggunaan Media Video Pada Mata Pelajaran Ipa Di Sekolah Dasar. Sekolah Dasar: Kajian Teori Dan Praktik Pendidikan, 28(2), 73-79.

Ristanto, R. H., Mahardika, R. D., \& Rusdi. (2021). Digital Flipbook Immunopedia ( Dfi ): A Learning Media To Improve Conceptual Of Immune System. Young Scholar Symposium On Science Education And Environment (Ysssee), 1-11. Https://Doi.Org/10.1088/1742-6596

Rizkasari, E., Huda, M. K., Marini, A., \& Sumantri, M. S. (2021). Development Of Digital Animation As A Learning Media In Primary Schools. The 5th Annual Applied Science And Engineering Conference (Aasec), 1-6. Https://Doi.Org/10.1088/1757-899x/1098/3/032068

Samatoa, U. (2016). Pembelajaran Ipa Di Sekolah Dasar. Jakarta Barat: Indeks.

Sari, Y., Sari, R. P., Sumantri, M. S., \& Marini, A. (2021). Development Of Digital Comic For Science Learning In Elementary School. The 5th Annual Applied Science And Engineering Conference (Aasec), 1-5. Https://Doi.Org/10.1088/1757-899x/1098/3/032060 Technology

Septikasari, R., \& Frasandy, R. N. (2018). Keterampilan 4c Abad 21 Dalam Pembelajaran Pendidikan Dasar. Jurnal Tarbiyah Al-Awlad, 7(2), 112-122.

Siregar, A., \& Siregar, D. I. (2021). Analisis Evaluasi Pengembangan Media Komik Digital Pada Mata Pelajaran Ipa Sekolah Dasar. Jasisfo (Jurnal Sistem Informasi), 2(1), 114-126.

Sukiman. (2012). Pengembangan Media Pembelajaran (1st Ed.). Yogyakarta: Pedagogia.

Sunami, M. A., \& Aslam. (2021). Pengaruh Penggunaan Media Pembelajaran Video Animasi Berbasis Zoom Meeting Terhadap Minat Dan Hasil Belajar Ipa Siswa Sekolah Dasar. Jurnal Basicedu, 5(4), 1940-1945. Https://Doi.Org/Https://Doi.Org/10.31004/Basicedu.V5i4.1129 Copyright

Wicaksono, J. W., Japar, M., \& Utomo, E. (2021). Development Of Digital Based Comic Media For Primary V-Class Student Learning. International Journal Of Multicultural And Multireligious Understanding (Ijmmu), 8(4), 532-537. Https://Doi.Org/Http://Dx.Doi.Org/10.18415/Ijmmu.V8i4.2601

Wulandari, A. R., Masturi, \& Fakhriyah, F. (2021). Pengaruh Media Pembelajaran Berbasis Youtube Terhadap 
1074 Media Digital dalam Memberdayakan Kemampuan Berpikir Kritis Abad 21 pada Pembelajaran IPA di Sekolah Dasar - Dewi Rahmawati Noer Jannah, Idam Ragil Widianto Atmojo DOI: https://doi.org/10.31004/basicedu.v6i1.2124

Hasil Belajar Ipa Siswa Di Sekolah Dasar. Edukatif: Jurnal Ilmu Pendidikan, 3(6), 3779-3785. Https://Doi.Org/Https://Doi.Org/10.31004/Edukatif.V3i6.1251

Yulyani, Kazumaretha, T., Arisanti, Y., Fitria, Y., \& Desyandri. (2020). Implementasi Kompetensi Pedagogik Guru Dalam Pembelajaran Tematik Di Sekolah Dasar. School Education Journal, 10(2), 184-188.

Zulherman, Amirullah, G., Purnomo, A., Aji, G. B., \& Supriansyah. (2021). Development Of Android-Based Millealab Virtual Reality Media In Natural Science Learning. Jurnal Pendidikan Sains Indonesia (Indonesian Journal Of Science Education), 9(1), 1-10. Https://Doi.Org/10.24815/Jpsi.V9i1.18218 